American J. of Engineering and Applied Sciences 1 (4): 408-413, 2008

ISSN 1941-7020

(C) 2008 Science Publications

\title{
Treatment of Wastewater by Natural Lagoon for its Reuse in Irrigation
}

\author{
M. Driche, D. Abdessemed and G. Nezzal \\ Laboratory Environmental-Engineering Processes, \\ Faculty of Mechanical Engineering and Processes Engineering, \\ University of Sciences and Technology Houari Boumedienne, B.P.32 El-Alia, \\ 16111 Bab-Ezzouar, Algiers
}

\begin{abstract}
The process of natural lagoon consists in purifying the waste water by simple flow of the effluent in not very deep ponds where proliferate bacteria, algae and other living organisms, under a surrounding air and in the presence of a solar radiation. For this study, which is spread out over 3 years (2004-2006) and which still continues, we chose the Beni Messous plant of purification by natural lagoon, to locate in Algiers. The parameters considered were: The biological oxygen demand $\left(\mathrm{BOD}_{5}\right)$, the Chemical Oxygen Demand (COD), nitrites $\left(\mathrm{NO}_{2}{ }^{-}\right)$, orthophosphates $\left(\mathrm{PO}_{4}{ }^{3}{ }^{-}\right)$, Suspended Solid (SS), $\mathrm{pH}$ and variation of the chlorophyll concentration. This lasts which made it possible to test the efficiency of this process for a possible reuse of the treated water, for the irrigation. The concentrations of the various parameters obtained after treatment the waste water by natural lagoon are as follows: 10 $\mathrm{mg} \mathrm{L}^{-1}$ of $\mathrm{BOD}_{5}, 12 \mathrm{mg} \mathrm{L}^{-1}$ of COD, $0.2 \mathrm{mg} \mathrm{L}^{-1}$ of nitrites, $1.4 \mathrm{mg} \mathrm{L}^{-1}$ of orthophophates, $75 \mathrm{mg} \mathrm{L}^{-1}$ of SS, $0.075 \mathrm{mg} \mathrm{L}^{-1}$ of Chlorophyll, the $\mathrm{pH}$ reaches values superior to 7 testifies to alkaline environment lagoon. These concentrations are generally lower than the standards irrigation.
\end{abstract}

Key words: Biologic wastewater treatment, lagoon, organic pollution

\section{INTRODUCTION}

Algeria counts among the countries with climate semi arid or arid, whose water's pollution comes to accentuate the water deficit caused by dryness, the volume of wastewater increases by day in day, whereas the natural resources decrease. But, this water, which is rejected into the nature, can constitute a true richness if it is treated with lower cost for reused in irrigation.

Thus, on the basis of this aspect we directed our research towards profitable and inexpensive wastewater treatment, such as the natural lagoon. This last is a system which reproduces the process of selfpurification of the aquatic environment ${ }^{[1]}$. It consists in making circulate water used to treat by gravity and permanently in one or series of basins where biological equilibrium will be established.

The contributions of the organic and nutritive matter in wastewater, constitute a favourable environment to the micro algae development in the lagoon, which produce oxygen by photosynthesis in the presence of necessary solar radiation has the life for the purifying micro-organisms ${ }^{[2]}$.
The principal advantage of this system is its simplicity operation, flexibility and its reliability, it is also characterized by the total absence of the apparatuses consuming energy (pump, aerator...), moreover, by physicochemical and biological quality suitable of treated water ${ }^{[3]}$.

\section{MATERIALS AND METHODS}

Description of lagoon: The sewage treatment plant by natural lagoon consists of four lagoons also said basins of treatment, of more or less rectangular lengthened forms.

Dimensioning and characteristics lagoons have given using a topographic study on the ground with a theodolite, measurements obtained are shown in Table 1, (DHEEWA, 2001) $)^{[4]}$.

The substratum attached to the ground water, is characterized by a good permeability. The likings and conglomerates which level of centre Algiers to the commune of Beni-Messous, contain a sheet which flowing by some small sources descending itself towards the Beni-Messous river. This sheet, related in

Corresponding Author: M. Driche, Laboratory Environmental- Engineering Processes, Faculty of Mechanical Engineering and Processes Engineering,University of Sciences and Technology Houari Boumedienne, B.P.32 El-Alia, 16111 Bab-Ezzouar, Algiers Tel: +21371 851243 Fax: +21321247919 
Am. J. Engg. \& Applied Sci., 1 (4): 408-413, 2008

Table 1: Dimensions of the various Beni Messous lagoons

\begin{tabular}{llcccr}
$\begin{array}{l}\text { No. } \\
\text { lagoon }\end{array}$ & $\begin{array}{l}\text { Length } \\
(\mathrm{m})\end{array}$ & $\begin{array}{l}\text { Width } \\
(\mathrm{m})\end{array}$ & $\begin{array}{l}\text { Depdth } \\
(\mathrm{m})\end{array}$ & $\begin{array}{l}\text { Surface } \\
\left(\mathrm{m}^{2}\right)\end{array}$ & $\begin{array}{l}\text { Volume } \\
\left(\mathrm{m}^{3}\right)\end{array}$ \\
\hline 1 & 90 & 310 & 4 & 27900 & 111600.0 \\
2 & 62 & 220 & 2 & 13640 & 27280.0 \\
3 & 42 & 130 & 1.5 & 5460 & 8190.0 \\
4 & 25 & 95 & 1.5 & 2375 & 3562.5 \\
\hline
\end{tabular}

the zone of the outcrop to the ground water is put in load towards the south under the blue marls. Small free sheets exist, they are fed exclusively by pluviometry and run out towards the sea ${ }^{[5]}$.

Geographical localization: The study zone is on the level of Beni Messous river. The latter is in the Algiers zone at west. It is attached to the Bouzareah administrative units and Cheraga.

The installation site of the Beni Messous lagoon plant is located between Ain Benian and Cheraga, on the secondary way road No. 11. It is distant $5 \mathrm{~km}$ of the river mouth of Beni Messous. Surface used is approximately 13 hectare. The study area is rather strongly built, but comprises nevertheless close agricultural zones.

For the calculation of the water residence time in each lagoon, the flow is considered as laminar. This last is considered constant in all the lagoons.

The residence time is calculated from the Eq. 1:

$$
\mathrm{Q}=\mathrm{V} / \mathrm{t}
$$

$\mathrm{Q}=$ Mean flow of wastewater entry $\left(\mathrm{m}^{3} / \mathrm{j}\right)$.

$\mathrm{V}=$ Lagoon volume $\left(\mathrm{m}^{3}\right)$.

$\mathrm{t}=$ residence time to say in day $(\mathrm{d})$.

The residence times of the various lagoons are:

$\begin{array}{ll}\text { 1st lagoon: } \mathrm{t} & =7 \text { days } \\ \text { 2nd lagoon: } \mathrm{t} & =2 \text { days } \\ \text { 3rd lagoon: } \mathrm{t} & =1 \text { day } \\ \text { 4th lagoon: } \mathrm{t} & =1 \text { day } \\ \text { global residence time: } \mathrm{t}=11 \text { days }\end{array}$

Climatic conditions: The climate is a significant factor in the life and the evolution of an ecosystem. The climatologists admit that the fundamental feature of the Mediterranean climate it estival dryness which can be more or less long ${ }^{[6]}$. Moreover, there is always one contrast between the cold season which are wet and the hot season which is dry. The area climate is a relatively rainy climate, tempered by the proximity sea. It falls under the Mediterranean climate and is characterized by one season wet of seven months and a dry season of five months which correspond to the estival period.

\section{RESULTS AND DISCUSSION}

The experimental study is based on followed temporal evolution of following parameters: $\mathrm{pH}, \mathrm{BOD}_{5}$, $\mathrm{COD}, \mathrm{NO}_{2}{ }^{-}, \mathrm{PO}_{4}{ }^{3-}, \mathrm{SS}$ and Chlorophyll concentrations at entry and exit of lagoon.

Variation of the $\mathbf{p H}$ : The $\mathrm{pH}$ is a significant parameter of the water quality, however it must be narrowly controlled during all the treatment ${ }^{[7]}$. According to Fig. 1, the $\mathrm{pH}$ values range between 7.5 and 8.8 , a light increase what supports the water decontamination ${ }^{[8]}$. This increase in the $\mathrm{pH}$ is due to the photosynthetic algae activity, who consumes $\mathrm{CO}_{2}$ dissolved in water ${ }^{[9]}$.It should be noted, that the $\mathrm{pH}$ conditions slightly alkaline, play a very significant role in the biological purification of the organic matter, as well as the purification nitrogenized by volatilization of ammonia $^{[10]}$.

Variation of the $\mathbf{B O D}_{5}$ : We notice, on Fig. 2 variation of the $\mathrm{BOD}_{5}$ of the treated water which does not depend on the carrying load in the lagoon, this confers to the latter a resistance against high pollution. Thus, the $\mathrm{BOD}_{5}$ is reduced on average from $255-10 \mathrm{mg} \mathrm{L}{ }^{-1}$ this value is conform with irrigation standard water, which is $10 \mathrm{mg} \mathrm{L}^{-1[11]}$.

The radar diagram in Fig. 3 position the $\mathrm{BOD}_{5}$ values of wastewater and treated water, compared to the rejection standards. According to this diagram, we note that the values obtained at the exit of the system, are in or very similar to the equilibrium band.

This fact, we can conclude from it that there is a considerable yield of the bacterial activity on the natural lagoons level.

Variation of the COD: We note that the COD of treated water does not depend on that of wastewater according to Fig. 4. The concentration of the COD is reduced on average from $320-12 \mathrm{mg} \mathrm{L}^{-1}$. The last is inferior with the irrigation standard, who is $187 \mathrm{mg} \mathrm{L}^{-1}$.

Variation of the nitrite concentrations: We note, according to Fig. 5 strong dependence between the concentration at the entry and the exit of the lagoon, we note that the mineral load allowed in the lagoon, influences considerably its purifying capacity.

The nitrite concentration is reduced on average from 1.9-0.2 $\mathrm{mg} \mathrm{L}^{-1}$. The minimal concentration is recorded during spring and summer.

These two periods are characterized by an intense algae proliferation which use these salts like a nutriment for the synthesis of their cellules ${ }^{[12]}$. 


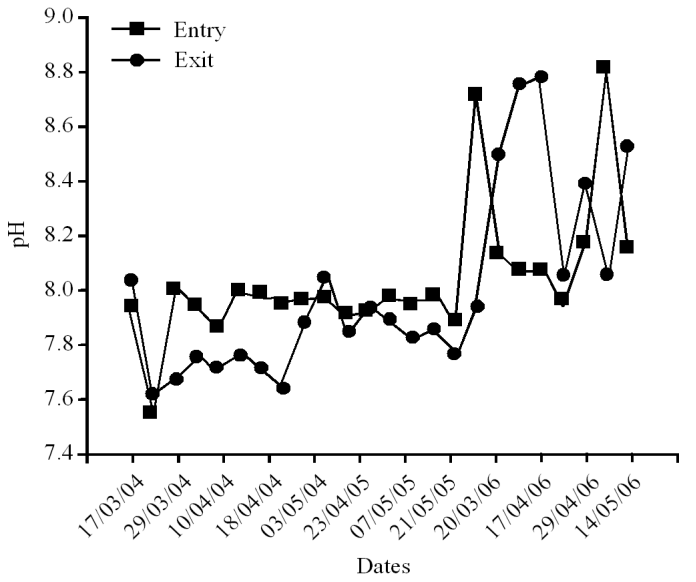

Fig. 1: Evolution of the $\mathrm{pH}$ according to time

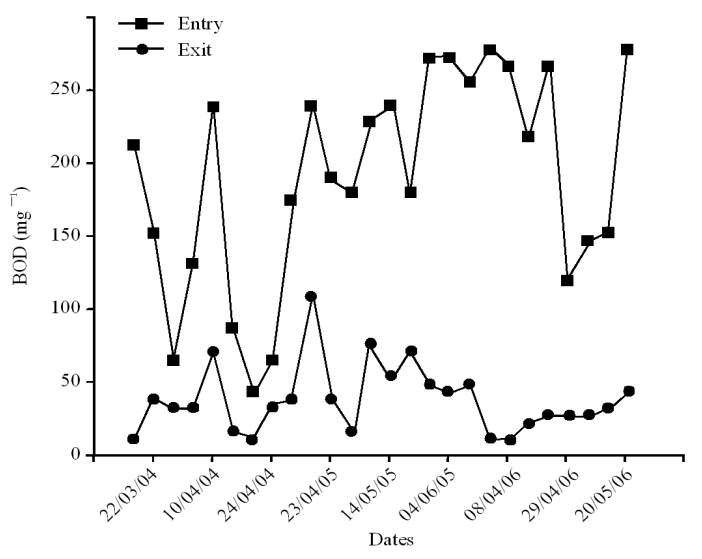

Fig. 2: Evolution of the $\mathrm{BOD}_{5}$ according to time

Variation of the Suspended Solid (SS) concentration: Figure 6 shows the variation of the wastewater suspended solid and that of treated water. At the lagoon entry, we note the presence of very significant values as of SS which lie between 400 and $600 \mathrm{mg} \mathrm{L}^{-1}$, had at the height discharge of the wastewater in the Beni Messous river, rich in particles likely to create a pollution by SS.

Water after treatment presents a low SS content lower than $100 \mathrm{mg} \mathrm{L}^{-1}$. The SS concentration is reduced on average of $500 \mathrm{mg} \mathrm{L}^{-1}$ with $75 \mathrm{mg} \mathrm{L}^{-1}$, with a yield of $85 \%$.

Variation of the chlorophyll and pheopigments concentrations: In Fig. 7 the curves of the average chlorophyll and pheopigments concentrations, show a tendency to decrease according to time, their variation is influenced by climatic factors $\left(\mathrm{T}^{\circ}\right.$, sunning...) and physicochemical parameters (turbidity, nutritive salts.... ${ }^{[13]}$.

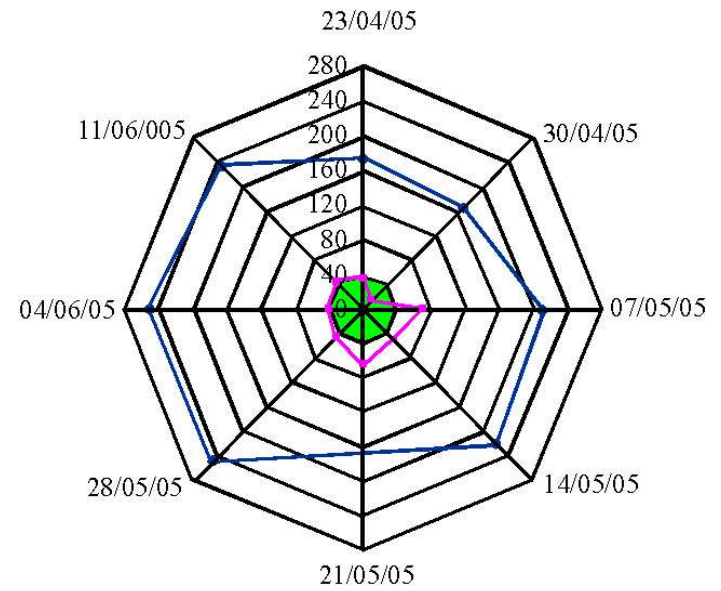

Fig. 3: The radar diagram

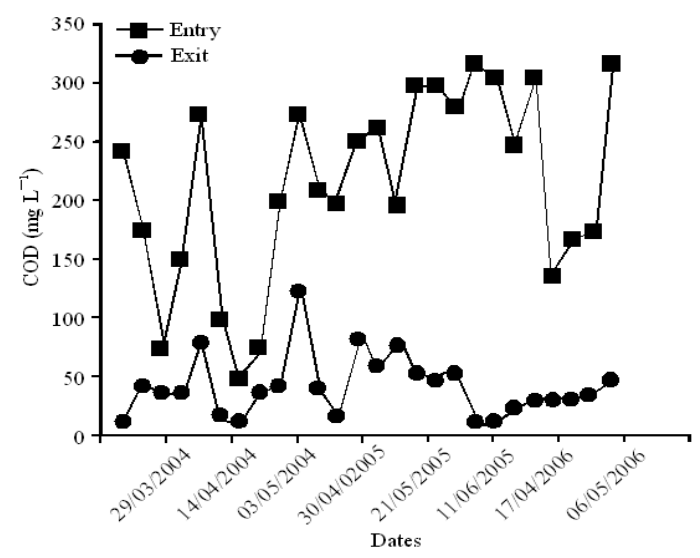

Fig. 4: Evolution of the COD according to time

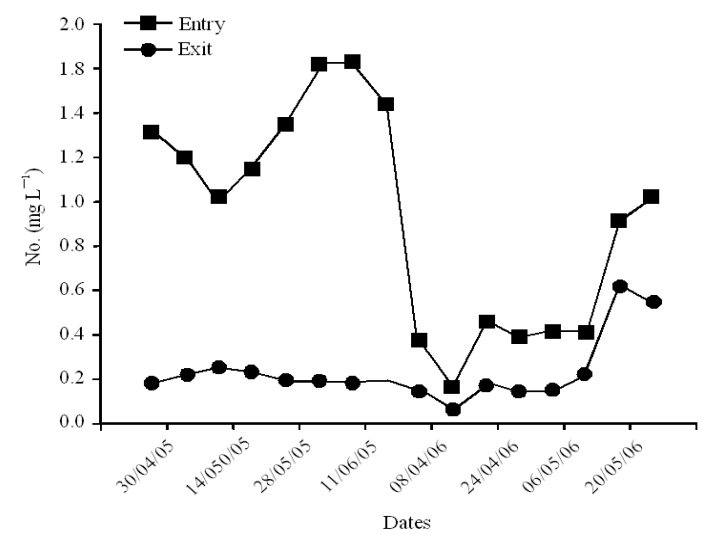

Fig. 5: Evolution of nitrite concentrations according to time

Spatial evolution of the physicochemical parameters and elimination yields according to the 
Am. J. Engg. \& Applied Sci., 1 (4): 408-413, 2008

Table 2: Evolution of the physicochemical parameters according to the number of lagoons

\begin{tabular}{lcccccc}
\hline No. of lagoons & $\mathrm{pH}$ & $\mathrm{BOD}_{5}\left(\mathrm{mg} \mathrm{L}^{-1}\right)$ & $\mathrm{SS}\left(\mathrm{mg} \mathrm{L}^{-1}\right)$ & $\mathrm{NO}_{2}^{-}\left(\mathrm{mg} \mathrm{L}^{-1}\right)$ & Chlorophyll $\left(\mathrm{mg} \mathrm{L}^{-1}\right)$ & ${\text { Pheopigment }\left(\mathrm{mg} \mathrm{L}^{-1}\right)}$ \\
\hline Lagoon No. 1 & 8.2 & 208.0 & 500 & 1.5 & 0.06 & 0.07 \\
Lagoon No. 2 & 8.4 & 70.0 & 125 & 0.7 & 0.09 & 0.10 \\
Lagoon No. 3 & 8.5 & 10.8 & 75 & 0.4 & 0.25 & 0.35 \\
Lagoon No. 4 & 8.3 & 6.0 & 75 & 0.2 & 0.01 & 0.03 \\
\hline
\end{tabular}

number of ponds: In order to study the efficiency of the sewage treatment plant by natural lagoon of Beni Messous, we calculated the elimination yield of each parameter for each pond during the treatment cycle. The yields are calculated by the following equation:

$$
\text { Elimination yield }(\%)=\frac{\text { Entry concentration }- \text { Exitconcentration }}{\text { Entry concentration }} \times 100
$$

In this part, we will be interested in the $\mathrm{pH}$ variations in each lagoon, with the concentrations elimination and yields of the $\mathrm{BOD}_{5}, \mathrm{SS}$, nitrites and orthophosphates, like the Chlorophyll and Pheopigments variations concentrations for each lagoon (B1, B2, B3, B4).

pH variation: The $\mathrm{pH}$ is a significant parameter for the evaluation of the water quality. The results obtained are represented in Table 2, we note that the values of the different $\mathrm{pH}$ slightly according to the lagoon, going on average from 8.2-8.5.

The most significant $\mathrm{pH}$ value is recorded at the 3rd intake point, at the level of the 3rd pond. This lagoon is characterized by a considerable alga proliferation of what explains the increase in $\mathrm{pH}^{[14]}$.

Evolution of the $\mathbf{B O D}_{5}$ elimination yield: We note according to Table 2, that the elimination yield evolution of the $\mathrm{BOD}_{5}$ varies in a decreasing way, we have a significant elimination yield in the first pond which is $66.5 \%$, then less significant yields on the level of the other lagoons, about $21.5 \%$ in the second pond, $6.8 \%$ in the third and $10.9 \%$ in the fourth pond. This variation, agree with those given by the theory ${ }^{[15,16]}$.

Evolution of the suspended solid elimination yield: We note according in Table 2, that the elimination of the suspended solid is observed primarily on the level of the first and second lagoon. The elimination yield in the first pond is very significant, $75 \%$ of the suspended solid are eliminated in this basin.

Evolution of the nitrites elimination yield: Table 2 shows the evolution nitrites elimination yield during the treatment. The elimination of nitrites is different from a lagoon with another, the majority of nitrites are eliminated from the first pond with an elimination yield

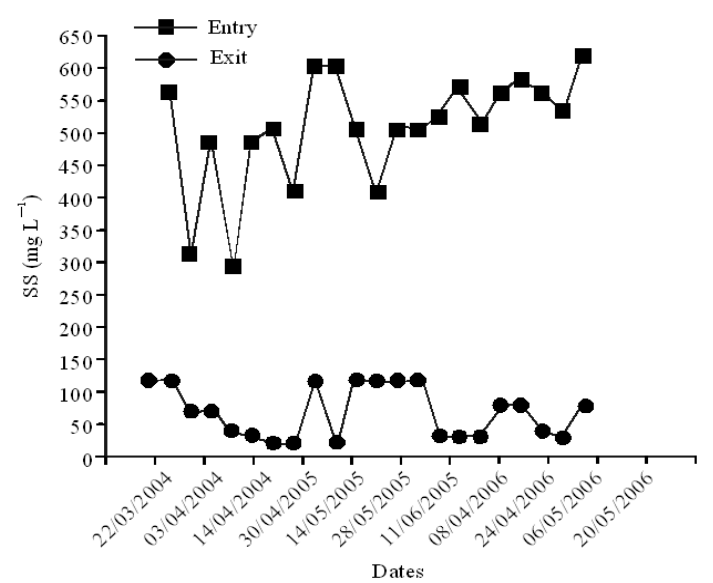

Fig. 6: Variation of SS concentrations according to time

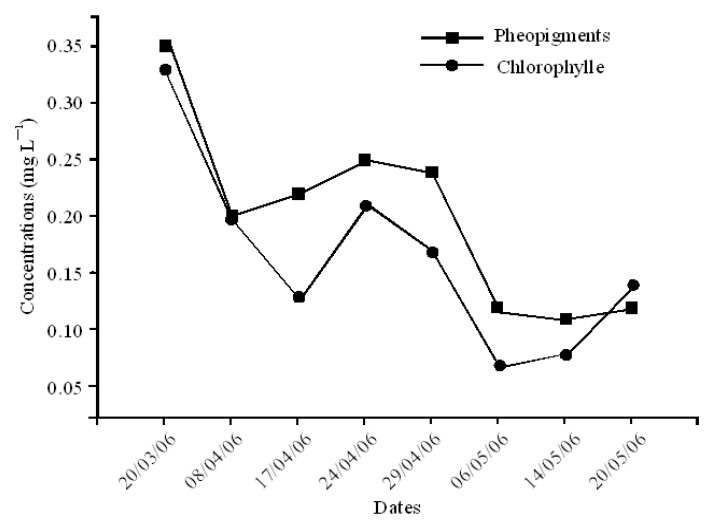

Fig. 7: Variation of chlorophyll and pheopigements concentrations according to time

of $55.36 \%$. We have nitrites elimination yield about $39.2 \%$ in the second pond, $29 \%$ on the third pond and $17.26 \%$ in the last pond.

Evolution of the chlorophyll and pheopigment concentrations: The evolution of the Chlorophyll and Pheopigment concentrations are represented in Table 2.

The highest Chlorophyll and Pheopigment concentrations are observed in the second and third lagoon where the conditions are met for a good algae production, at the entry of pond, strong turbidity prevents the penetration of the light, at the exit, the 


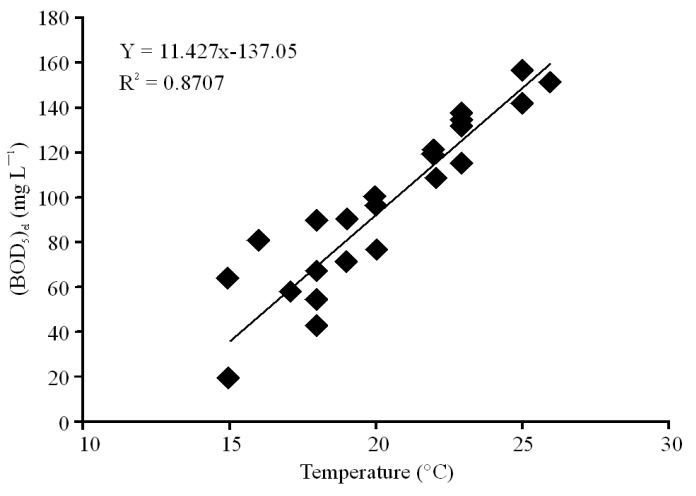

Fig. 8: Evolution of the eliminated concentration of the $\mathrm{BOD}_{5}$ according to the temperature

weak chlorophyll and pheopigment concentration is due probably to the reduction of nutritive salts as well as the zooplankton proliferation which uses micro algae, like nutrition sources ${ }^{[17]}$.

Evolution of the eliminated $\mathrm{BOD}_{5}$ concentration according to the temperature: We will be interested, for modelling study, with the evolution of the eliminated biochemical demand for oxygen $\left(\left[\mathrm{BOD}_{5}\right]_{\mathrm{el}}\right)$ according to the temperature, the average concentrations of the $\mathrm{BOD}_{5}$ are calculated from the values recorded before and after treatment.

The object of this study is to highlight the influence of the temperature on the capacity of study lagoons treatment and therefore, the correlation which exists between the evolution of the organic load represented by the $\mathrm{BOD}_{5}$ and the temperature of the environment lagoon.

From the line shown in Fig. 8, a proportional increase in the eliminated $\mathrm{BOD}_{5}$ concentrations of the according to the temperature, is observed.

The average concentrations of the biochemical demand for oxygen during the first taking away are about 55-115 $\mathrm{mg} \mathrm{L}^{-1}$ with temperature varying of 17 $20^{\circ} \mathrm{C}$. That is explained by a sampling in spring period. These concentrations are significant during the last taking away, they vary from $140-147.5 \mathrm{mg} \mathrm{L}^{-1}$ with temperature of about 21 with $24^{\circ} \mathrm{C}$, that is due to a sampling in estival season.

The effect of the temperature on the $\mathrm{BOD}_{5}$ follows a linear law of the following form:

$$
\left[\mathrm{DBO}_{5}\right]_{\mathrm{el}}=11.427 \mathrm{~T}\left({ }^{\circ} \mathrm{C}\right)-137.05
$$

With a coefficient of correlation: $\mathrm{R}^{2}=0.87$.

This study pushes us to conclude that the temperature has a very significant effect on the purification capacity for natural lagoon, this conclusion is in agreement with the theory ${ }^{[18]}$.

\section{CONCLUSION}

This study, undertaken for one 3 years period, made it possible to evaluate the efficiency of the wastewater treatment by a process little known in Algeria which is the natural lagoon for a possible reuse of the treated effluent in irrigation.

The results obtained compared with the irrigation standards, show that the $\mathrm{BOD}_{5}$ concentration of treated water is sometimes higher than the standard $(10 \mathrm{mg}$ $\mathrm{L}^{-1}$ ), which leads us to consider a periodic control of water at the exit of the lagoon.

The values of the COD concentration are lower than the irrigation standards $\left(150 \mathrm{mg} \mathrm{L}^{-1}\right)$, the weak nutritive salts concentrations are obtained during the seasons of spring and summer, periods characterized by a significant sunning rate and consequently, a considerable micro algae proliferation which use nutritive salts for the synthesis of their cellular material.

The elimination of the suspended solid is about $95 \%$, announce that greatest elimination was recorded in the first pond where we noted a significant reduction in turbidity. This means that, the first lagoon played the role of a decantation lagoon, this conclusion is in agreement with the results given by the theories ${ }^{[19,20]}$.

The correlation tests show that the reduction of organic pollution strongly depends on the temperature, consequently, the best elimination yield and thus the weakest organic loads are recorded during the estival period.

The present study, relates to the waste water treatment by natural lagoon, a purification technique which depends on several factors: the topography of the ground, geology, climatologically conditions and the effluent nature.

This process which ensures by its effectiveness of treatment, the environmental protection and the possibility of reuse of the waste water treated for the irrigation, is best adopted by the countries in the development process, because it presents a weak investment capital and low energy consumption.

Lastly and according to the obtained results, the purification technique of the waste water by natural lagoon, can be advantageously used and in encouraging way for the reuse of the waste water in agriculture in our country, considering its temperate climate on the one hand and the choice which it offers as regards the quality and of the availability of the grounds, on the other hand. This leaves with saying that the rational management of the natural resources can be done only 
by the importance which one attaches to the water quality and not only to their quantities.

\section{REFERENCES}

1. Edeline, F., 1988. Epuration biologique des eaux résiduaires: Théorie et technologie. Techniques et Documentation, Ed. Lavoisier, Paris.

2. Champiat, D. and J. Larpent, 1988. Biologie des eaux : méthodes et techniques, Ed. Masson, Paris.

3. Fresenius, W. and W. Shneider, 1990. Technologie des eaux résiduaires. Ed. Springer Verlag, Berlin, pp: 527.

4. Direction de l'hydraulique et de l'économie de l'eau de la wilaya d'Alger (DHEEWA), 2001. Document interne.

5. Agence nationale des ressources hydriques (A.N.R.H), 1996. Étude de la faisabilité de lagunage sur les hauts plateaux, 20.

6. ONM (Office National de la Météorologie) de Dar El Baida, 2005. Document interne.

7. O.M.S/P.N.U.E. 1995. Recommandation pour la surveillance sanitaire des zones côtières à usage récréatif et des zones conchylicoles: Recommandations Générales, I: 45-47.

8. Boukef, I., 2003. Qualité bactériologique de quelques effluents urbains traités et rejetés dans l'environnement. Proceedings des actes du Séminaire International. Institut National des Sciences et Technologie de la Mer. Tunis.

9. Bowes, G. and S. Beer, 1987. Physiological Plant Processes: Photosynthesis Aquatic plant. Wastewater Treatment and Resource Recovery. Magnolia Publishing Inc, pp: 311-335.

10. Reddy, K.R., 1984. Nutrient transformation in aquatic macrophyte filters used for water purification. Water Works Ass, 2/3: 660-678.
11. AL-Ahmed, M., F. Abdul, K. Al-Humaizi and A. AL-Khodair, 1999. The application of flow sheeting technology in waste water treated and water. The International Desalination and water reuse No. $=6$

12. Minocha, V.K. and R. Prabbhakar, 1988. Ammonia removal and recovery from urea fertilizer plant waste. Environ. Technol. Lett., 9: 655-664.

13. Canovas, S., B. Picot, C. Casellas, H. Zulkifi, A. Dubois and J. Bontoux, 1996. Seasonal development of phytoplankton and zooplankton in high-rate algal pond. Wat. Sci. Tech., 33: 199-206.

14. Bowes, G. and S. Beer, 1987. Physiological plant processes: Photosynthesis Aquatic plant. Wastewater treatment and resource recovery. Magnolia Publishing Inc: 311-335.

15. Kumar, P. and R.J. Garde, 1990. Upgrading wastewater system by water hyacinth in developing centuries. Water Sci. Technol., 22: 153-160.

16. Edeline, F., 1993. L'épuration biologique des eaux. Théorie et technologie des réacteurs. Liége, Cebedoc Editeur, pp: 303.

17. Canovas, S., C. Casellas, B. Picot, G. Pena and J. Bontoux, 1991. Evolution annuelle du peuplement zooplanctonique dans un lagunage à haut rendement et incidence du temps de séjour. Rev. Sci. Eau, 4: 269-289.

18. Ouazzani, N., 1998. Thèse d'état, univérsité Caddi Ayyad, Marrakech, pp: 315.

19. Kim, Y., W.J. Kim, P.G. Chung and W.O. Pipes, 2001. Control and separation of algae particles form WSP effluent by using floating aquatic plant root mats. Water Sci. Technol., 11: 315-322.

20. Kim, Y. and W.J. Kim, 2000. Roles of water hyacinths and their roots for reducing algal concentration in the effluent from waste stabilization pond. Water Res., 13: 3285-3294. 